\title{
INFORMAL DISPUTE RESOLUTION BASED ON ADAT LAW: A CASE STUDY OF LAND DISPUTE IN FLORES, EAST NUSA TENGGARA, INDONESIA
}

\author{
Najmu L. Sopian* \\ * Masters candidate, International Legal Studies, New York University
}

\section{Article Info}

Received : 8 June 2015 | Received in revised form : 10 July 2015 | Accepted : 27 July 2015

Corresponding author's e-mail : najmulaila.sopian@gmail.com

\begin{abstract}
The issue of law enforcement is central to land property rights. Modes of property rights enforcement can be performed either with or without intervention of the state. This article focuses on the latter mode of enforcement; that is, how people manage to enforce their land rights without the involvement of state institutions and to what extent informal arrangements can offer effective enforcement and secure land property rights. This article also contributes to the debate on how formal and informal institutions can be used to secure property rights and resolve disputes over land ownership. In particular, this paper examines how the people of Flores, East Nusa Tenggara Province, settle land disputes among themselves. Many available studies indicate that the residents of Flores rely heavily on informal land dispute resolution based on adat (customary) law rather than formal or legal rules. Adat provides certain sense of security and has been proven effective in resolving conflicts in a relatively closed and homogenous community. Moreover, it offers greater accessibility, flexibility and legitimacy that support reconciliation process between the disputing parties.
\end{abstract}

Keywords: informal dispute resolution, adat law, flores, informal institutions.

\begin{abstract}
Abstrak
Isu penegakan hukum merupakan masalah inti dalam perlindungan hak-hak kebendaan atas tanah. Perlindungan atas hak kebendaan tersebut dapat diberikan baik oleh Negara maupun oleh aktor-aktor lain selain Negara. Artikel ini fokus pada perlindungan yang diberikan oleh aktor bukan Negara, yaitu bagaimana masyarakat mampu untuk melindungi hak-hak kebendaan mereka tanpa keterlibatan institusi Negara. Pertanyaannya adalah,sejauh mana institusi informal dapat bekerja secara efektif untuk memberikan perlindungan atas hak kebendaan atas tanah? Artikel ini juga berkontribusi terhadap debat mengenai bagaimana institusi formal dan informal dipergunakan oleh masyarakat untuk melindungi hak milik mereka dan untuk menyelesaikan konflik terkait dengan tanah dalam masyarakat. Secara khusus, artikel ini membahas mengenai bagaimana masyarakat di Flores, Nusa Tenggara Timur mempergunakan hukum adat untuk menyelesaikan konflik yang terjadi dalam masyarakat. Berbagai penelitian menunjukkan bahwa masyarakat Flores masih sangat bergantung kepada mekanisme hukum Adat ketimbang hukum nasional. Hukum Adat terbukti memberikan perlindungan kuat terhadap hak kebendaan dan dapat mengatasi konflik secara efektif, terutama dalam sebuah komunitaskecil yang homogen. Selain itu, hukum Adat memberikan akses yang lebih besar, lebih fleksible, dan memiliki legitimasi yang kuat dalam proses rekonsilitasi diantara para pihak yang bersengketa.
\end{abstract}

Kata Kunci: penyelesaian sengketa informal, hukum adat, flores, institusi informal. 


\section{Introduction}

Informal dispute resolution, "informal justice," ${ }^{1}$ or "traditional justice system"2 is the most common type of dispute settlement in Indonesia and is typically applied by members of the lower class who live in rural areas or poor urban communities. ${ }^{3}$ This paper defines informal dispute resolution as any kind of dispute settlements that are reached outside formal adjudication system. This definition includes dispute resolution based on adat law. Adat literally means custom or tradition. In this paper, the term adat is used to refer to informal institutions connoting "particular timehonored practices and institutions, inherited by communities rather than imposed by the state." ${ }^{4}$ Control over territory and other natural resources is at the core of conflicts and struggles in Indonesia ${ }^{5}$ and is one of the central issues in adat law.

Asia Foundation shows that informal mechanisms are the preferred method for solving disputes over the past ten years. This study found that only $18 \%$ of the respondents pursued settlements and defended their interests through formal institutions, while $57 \%$ used informal means, and $32 \%$ chose to bury their grievances and do nothing. ${ }^{6}$ The World Bank estimates an even higher use of non-state justice system and claims that as many as $90 \%$ of disputes in Indonesia have been processed using informal adjudication system. ${ }^{7}$

To some extent, citizens' preference for informal solutions over the formal ones can be attributed to their perceptions of the state judiciary as "highly corrupt," "complicated," "expensive," and offering limited flexibility. The ineffectiveness of formal institutions reduces incentives for people to use these institutions for adjudicating their disputes. ${ }^{8}$ Informal mechanisms, on the other hand, are perceived to be "quicker, cheaper, and easier," and thus more attractive than the formal system. ${ }^{9}$

1 The World Bank defines informal justice as "local dispute resolution - arbitration and mediation practiced by village heads, traditional customary leaders, neighborhood leaders and religious leaders sometimes based on tradition, but equally often on the subjective assessment of community leaders without explicit reference to either state or customary law." World Bank, Justice for the Poor: Forging the Middle Ground: Engaging Non-State Justice in Indonesia [Menemukan Titik Keseimbangan: Mempertimbangkan Keadilan Non-Negara di Indonesia], (Jakarta: World Bank, 2009), p.ix.

2 Sinclair Dinnen, “'Traditional' Justice Systems in the Pacific, Indonesia and Timor-Leste," (presented at The 2009 Justice for Children in the Pacific, Indonesia and Timor-Leste, EAPRO Sub-Regional Workshop, April 2009), www.unicef.org/tdad/uniceftradpacificindonesiatimor09.doc, accessed 1 March 2014.

${ }^{3}$ World Bank, loc.cit.

${ }^{4}$ Jamie S. Davidson and David Henley(1), "Introduction: Radical Conservatism - The Protean Politics of Adat" in The Revival of Tradition in Indonesian Politics: The Deployment of Adat from Colonialism to Indigenism, edited by Jamie S. Davidson and David Henley (New York: Routledge, 2007), p. 3.

${ }^{5}$ John R. Bowen, Islam, Law, and Equality in Indonesia (Cambridge: Cambridge University Press, 2003), p. 63. See also Davidson and Henley (1), op.cit., p. 3.

6 Asia Foundation, Citizens' Perceptions of the Indonesian Justice Sector (Jakarta: Asia Foundation, 2001).

7 Non-state justice is defined as "all forms of dispute resolution besides formal court adjudication." World Bank, op.cit., p. 4. See also Stephen Golub, "Beyond Rule of Law Orthodoxy: the Legal Empowerment Alternative," Working Paper No. 14, (Washington DC: Carnegie Endowment for International Peace, 2003).

${ }_{8}$ The survey by Asia Foundation shows that general court and police are perceived as ineffective because they are "unreliable, disrespectful, arrogant, corrupt, apt to demand bribes, ignores human rights and serves the wealthy." In contrast, informal institutions such as community leaders, religious leaders, and religious court are considered as effective, with positive assessments such as "trustworthy, does job well, timely, helpful, the first to go to with a legal problem." Asia Foundation, op.cit., p. 5.

${ }^{9}$ The World Bank Social Development Unit of Indonesia, "Village Justice in Indonesia: Case Studies on Access to Justice, Village Democracy, and Governance," (a report from Justice for the Poor Team, The World Bank Social Development Unit of Indonesia, February 2004), p. 7, http://siteresources.worldbank.org/IN- 
As Davidson and Henley observe, "where the rule of the state law is weak or absent, people depend heavily on each other's co-operation for substance and security."

This article illustrates property rights enforcement through informal institutions by examining dispute resolution mechanism in Flores, East Nusa Tenggara Province. ${ }^{11}$ The analysis proceeds in four sections. The first section discusses adat in general and its relation to legal pluralism in a post-colonial country. It then examines adat institutions in Flores, the role of adat chiefs in enforcing property rights, and how local people manage to enforce their land rights without the involvement of state apparatus. Furthermore, it analyzes the nature of adat as informal institutions, to what extent adat falls in the category of informal institutions, and how informal land rights institutions affect the formal ones. Finally, it also contributes to the theoretical debate on property rights institutions.

\section{Adat, Legal Pluralism, and the Colonial Legacies}

Legal pluralism is a phenomenon that often occurs in post-colonial countries, in which an indigenous self-regulating system has persisted under the cumulative weight of colonialism, modernization, and globalization. ${ }^{12}$ Dinnen defines legal pluralism as "a situation where multiple forms of law co-exist within a single environment or setting." ${ }^{13}$ Favali and Pateman, on the other hand, employ a stronger definition of legal pluralism as coexistence that involves not only various rules but also multiple actors who produce law. ${ }^{14}$ That way, they incorporate institutional elements whose legitimacy originates outside the state power.

Indonesia is a country with high level of internal diversity. It is home to 300 ethnic groups with more than 700 languages and dialects spoken, making Indonesia one of the most heterogeneous countries in the world. ${ }^{15}$ Long before the arrival of colonial powers in Indonesia several centuries ago, many local communities had operated within their self-regulating systems with multiple political entities. ${ }^{16}$

The Dutch colonization brought about massive changes to the Indonesian political and legal system. In the mid- $19^{\text {th }}$ century, the Dutch established colonial administration based on the politics of divide and rule (devide et impera) for furthering their gains. They separated the population into three racial groups, placing Europeans as the first class race, Foreign Orientals (including Chinese, Arabians, and Indians) as the second, and Native Indonesians (inlanders) as the third class. Each group was subject

TINDONESIA/Resources/Publication/04Publication/VilllageJustice+.pdf, accessed on 1 March 2014.

${ }^{10}$ Davidson and Henley (1), op.cit., p.19.

${ }^{11}$ Enforcement of land rights can be understood as the capacity to defend rights against other parties' illegal eviction. The enforcement of property rights can be seen through how institutions (either formal or informal ones) can effectively resolve land disputes and provide a "coherent property rights system. "Kathryn Firmin A. Sellers, "The Politics of Property Rights," American Political Science Review Vol. 89 No. 4 (December 1995): 867-881. See also: Douglass C. North (1), "Institutions and Credible Commitment," p. 3, http://dlc.dlib.indiana.edu/dlc/bitstream/handle/10535/3711/9412002.pdf?...1, accessed on 24 February 2014.

${ }^{12}$ Dinnen, loc.cit.

${ }^{13}$ Ibid., p. 2.

${ }^{14}$ Lyda Favali and Roy Pateman, Blood, Land, and Sex: Legal and Political Pluralism in Eritrea (Bloomington: Indiana University Press, 2003), p. 2.

${ }^{15}$ Dinnen, op.cit., p. 19. See also the Embassy of the Republic of Indonesia, “A Diverse National," http:// www.embassyofindonesia.org/about/people.htm, accessed on 15 March 2014.

${ }^{16}$ Davidson and Henley (1), op.cit., p. 3. 
to different laws, courts, and procedures. ${ }^{17}$

After its independence in 1945, the Indonesian government had to deal with a pluralist legal system comprising a combination of adat, colonial inheritance, and Islamic legal influences. Despite decades of effort to unify legal systems in a formally codified law, Indonesia today still witnesses the persistence of customary institutions (adat), particularly in the outer islands (outside Java). Adat is a set of principles, values, and local wisdoms that are embedded in a particular society and serves as an integral part of indigenous social orders. Its main function is the preservation of order and harmony within the society.

For the sake of simplicity, this article loosely defines adat law as customary law, although Hooker argues that it has a broader meaning beyond that definition. The term of adat can refer to one of the following: "law, rule, precept, morality, usage, custom, agreement, conventions, principles, the act of conforming to the usage of society, decent behaviour, ceremonial, the practice of magic, sorcery, rituals." Therefore, he contends that the precise meaning of adat depends upon a particular context. ${ }^{18}$

Despite facing challenges under state repression as well as modernity and globalization, these adat institutions have not perished. Instead, they continue to be one of the primary sources of law and provide an important informal mechanism of conflict management at the local level. The persistence of adat, particularly in the outer islands, shows that national law never fully supersedes adat. Instead, as Dinnen notes, adat has proved remarkably resilient and continues to "adapt to the local and external dynamics of social change." ${ }^{19}$

Although at local level people are inclined to use adat institutions as the primary legal source and show less reliance on the state-centred law, adat still receives limited recognition at national level. Adat and legal pluralism to some extent are seen as a potential threat to the national unity and stability. The Indonesian Constitution and its later amendments recognize adat laws provided that they still exist in the society and do not contravene the state law. Government policies are bent toward the unification of the legal system, abandoning legal pluralism in the society and leaving adat institutions at the periphery. The role of national law was strengthened at the cost of adat law. ${ }^{20}$

The demise of Suharto's regime in 1998 was followed by an emerging exigency of the people's demanding the renaissance or the revival of adat. The proponents of the "adat revivalism movement" see adat as the "source of justice" to restore the damage caused by the New Order regime and as the symbol of "national identity" and "solidarity." 21 They seek the advancement of autonomy and resource distribution as

17 For further reading about the history of Indonesian legal system, see: Sebastiaan Pompe (1), The Indonesian Supreme Court: A Study of Institutional Collapse (Ithaca: Cornell Southeast Asia Program Publication, 2005). See also Bowen, loc.cit.

${ }^{18}$ M. B. Hooker, Adat Law in Modern Indonesia (New York: Oxford University Press, 1978), p. 50.

${ }^{19}$ Dinnen, op.cit., p. 2

${ }^{20}$ Sebastiaan Pompe (2), "Between Crime and Custom: Extra-marital Sex in Modern Indonesian Law," in Indonesia, Law and Society, 2nd ed., edited by Tim Lindsey (New South Wales: The Federation Press, 2008), p. 106.

${ }^{21}$ The most notable damage done by Suharto's New Order (1966-1998) was the uniformity of local bureaucratic structure through the Law Number 5 Year 1974, causing the abolishment of local diversity and adat institutions at the local levels. The law replaced adat leaders and other adat institutions with "elected but state-screened village headmen" operating within standardized bureaucratic fashion that resembles the Javanese's village structure "desa” (rural village). See Jamie S. Davidson and David Henley (2), eds., The 
well as the recognition of their institutions. ${ }^{22}$

As Davidson and Henley note, "the rise of indigenous movement is often thought of as the continuation at sub-national level of an old tradition of anti-imperialism." ${ }^{23}$ In Indonesian context, the revivalism of adat has become "the paradox of the postNew Order era." ${ }^{24}$ On the one hand, adat is seen as a potent tool for "redressing past injustices." It is believed to be the cure for Indonesia's chronic corruption and ineffective institutions as well as the means to "promote more democratic forms of village government." 25 It is also often linked to the notions of "territorial sovereignty," "the rights to access to justice and economic resources," and other "indigenous rights." 26

On the other hand, while adat is often viewed with certain levels of appreciation and sympathy, it nevertheless presents a number of key weaknesses. The major concerns are "political hierarchy" and "legitimation of social inequality" within the community as well as the exclusion of other ethnic groups and settlers. ${ }^{27}$ Adat tends toward inequality because a large portion of power is centred in the hands of adat chiefs as well as local or customary elites. As Tania Li points out, adat "tend[s] to privilege elites, especially senior men, who are empowered to speak on behalf of a presumed whole," leaving women disempowered. ${ }^{28}$

In addition, adat institutions lack checks and balances because there is no division of powers between judiciary and other governmental organs within adat. Due to its unwritten nature, principles and dispute resolution procedures in adat have often been "loosely defined." 29 With the lack of internal accountability structures, adat institutions are apt to have a greater possibility for creating abuse of power. Also, while the revival of adat has strengthened ethnic identity and communal bonds, at the same time it has generated the exclusion of outsiders.

In the next section, this paper presents a narrative description of adat institution in Flores, its relationship with national law, and how adat is implemented as a substitution for state law in resolving conflicts in Flores. It also seeks to answer these questions: (1) who can be appointed as adat leaders? and (2) what are the sources of their authority? This paper also discusses how adat responds to modern challenges and how it is used in current situations.

\section{Case Study: Land Dispute Resolution in Flores}

\section{A. A Glimpse of Flores, East Nusa Tenggara}

In order to explain the role of adat in resolving land disputes, this paper employs

Revival of Tradition in Indonesian Politics (London: Routledge, 2007), pp. 10, 23 and 32.

${ }^{22}$ Adriaan Bedner and Stijn van Huis, "The Return of the Native in Indonesian Law: Indigenous Communities in Indonesian Legislation," Bijdragen tot de Taal-, Land-en Volkenkunde Vol. 164 No. 2/3 (2008): 167.

${ }^{23}$ Davidson and Henley (1), op.cit., p. 5.

${ }^{24}$ Ibid. p. 18.

${ }^{25}$ Ibid. p. 4.

${ }^{26}$ Ibid. p. 6.

${ }^{27}$ Ibid. p. 4.

${ }^{28}$ Tania M. Li, "Adat in Central Sulawesi: Contemporary Deployments" in The Revival of Tradition in Indonesian Politics, edited by Jamie S. Davidson and David Henley, (London: Routledge, 2007).

${ }^{29}$ Davidson and Henley (1), op.cit., p. 21. 
a case study of dispute resolution in Flores, East Nusa Tenggara Province. Flores is a small island situated in eastern Indonesia, with an area of 14,300 square kilometers that are divided into eight regencies. ${ }^{30}$

\section{Picture 1: Map of the Flores Island ${ }^{31}$}

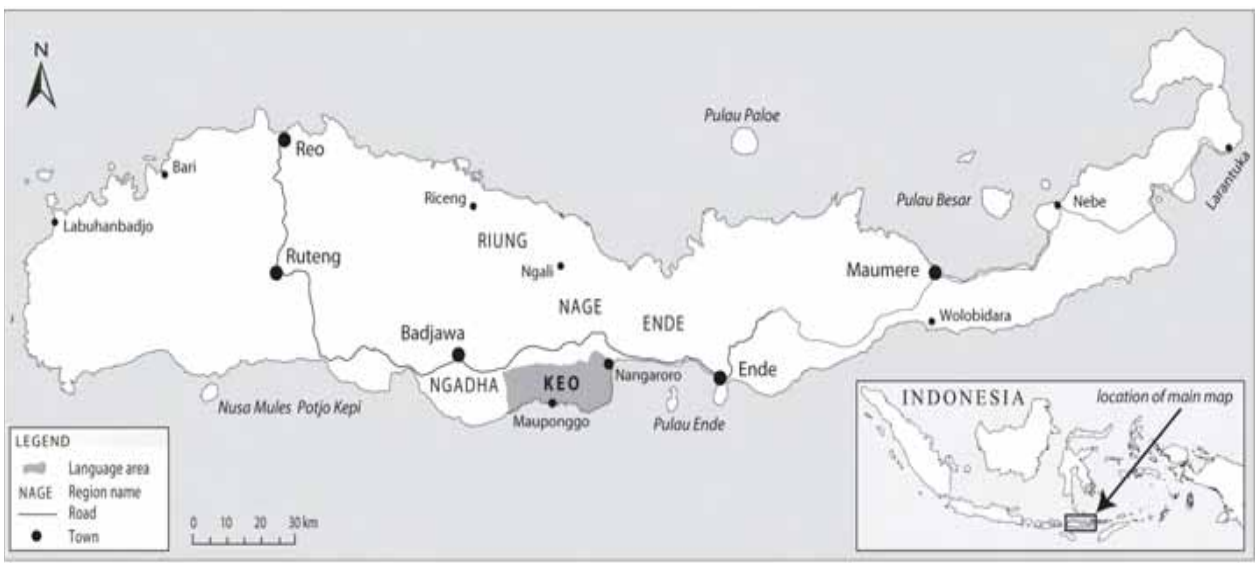

The Flores population is predominantly Catholic, ${ }^{32}$ in stark contrast to other Muslim-majority regions in Indonesia. The Catholic domination is attributed to Flores' distinct history. Unlike the other parts of Indonesia, Flores was colonized by the Portuguese for centuries before it was sold to the Dutch in 1859. The name of Flores itself originated from the Portuguese word for flowers. Portuguese traders and missionaries spread Christianity in eastern Indonesia, including Flores. In the subsequent colonization, the Catholic Church brought modernization to Flores through schools, health centres, and social outreach. ${ }^{33}$

Adat plays a significant role in the maintenance of order and day-to-day life of the people of Flores. ${ }^{34}$ It provides an important framework for the socio-political order and constructs behavioural patterns in Flores. One of the distinct features of adat is its universal and magic-religious nature. In adat system, "man, community and the supernatural are seen as indistinguishable parts of a unitary whole." 35 The main function of adat is, thus, to maintain and preserve harmony among people,

\footnotetext{
${ }^{30}$ They are (1) West Manggarai, (2) Central Manggarai, (3) East Manggarai, (4) Ngada, (5) Nagekeo, (6) Ende, (7) Sikka, and (8) East Flores.

${ }^{31}$ Antropologi Indonesia, 56 (XXII): 70.

32 It was recorded that 128,915 out of 138,050 of the population are Catholics. Department of Religious Affairs of Ngada 2008, in the Statistics of Ngada Regency. BPS Statistics of Ngada Regency, Ngada dalam Angka 2009 [Ngada in Figures 2009], (Ngada: BPS Statistics of Ngada Regency, 2009), p. 146.

33 John Mansford Prior, "Land Disputes and the Church: Sobering Thoughts from Flores," in Land for the People: The State and Agrarian Conflict in Indonesia (Ohio University Research in International Studies, Southeast Asia Series No. 126), edited by Anton Lucas and Carol Warren, (Athens: Ohio University Press, 2013), p. 216.

${ }^{34}$ Maria D. Muga, "The Role of the Chief of Adat in Land Conflict Resolution through Mediation: Case Study Ulayat Land Case at the District of SOA, Ngada, Flores, East Nusa Tenggara," ["Peranan Kepala Adat dalam Penyelesaian Sengketa Tanah Ulayat Melalui Mediasi: Studi Analisa Terhadap Penyelesaian Sengketa Tanah, Tanah Ulayat di Kecamatan SOA Kabupaten Ngada, Flores, Propinsi Nusa Tenggara Timur"], (Thesis at the Magister Program of Notary, University of Diponegoro, Semarang, 2008).

${ }^{35}$ Sebastiaan Pompe (2), op.cit., p. 121.
} 
community, and nature. ${ }^{36}$ Adat is usually unwritten; it is transmitted orally through generation after generation and is reaffirmed by the decision of the chief of adat.

The people of Flores view adat as the primary source of law in managing natural resource distribution among members of the society, enforcing their rights, and resolving conflicts over land. According to adat law, all land in Flores including forests is considered as communal land and belongs to a particular tribal group (woe) in a given territory. The rights over communal land are often referred to as hak ulayatulayat literally means territory or area, and hak means rights. Hak ulayat thus means rights to a territory or area subject to adat law.

The enforcement of these rights relies heavily, if not exclusively, on the chief of adat (Mosalaki). The unwritten laws of adat place the chief of adat in an extremely privileged position and give him the authority to attach his own meaning or to interpret the enforcement of adat laws. The power of adat institutions is centred on the chief of adat as he is seen as an essential intermediary or link between the mundane and the supernatural worlds. The chief of adat is perceived as the adat authority, serving to maintain peace and order in the society.

The legitimacy of the chiefs of adat originates from their ancestors, is transmitted by patrilineal lineage, and is maintained through social hierarchies embedded in adat structure. ${ }^{37}$ The origin of their forefathers is a key criterion to explain their legitimacy. In Flores, power relations and social hierarchies within the society are initiated, developed, and maintained according to the system of precedence of their ancestors.

Historically, the people of Flores believe that their ancestors migrated from outside the island through the northern coast of Flores. These first generation settlers and their descendants are called ata nggoro. They are believed to be the first who opened land and built settlements, paving the way for the establishment of social order in Flores. Newcomers and their descendants who came after the villages had been established are called ata mai. ${ }^{38}$

The history of the origin of Flores people determines their place in the stratification of social life and social relations. As the first settlers, ata nggoros are perceived to deserve more privileges than ata mai for their meritorious contributions to community building at the earlest stages of their history. This "first-come, firstserved principle" continues to shape social structures within the society in which ata nggoros enjoy advantages over ata mais, including exclusive authority over natural resources and adat institutions. Only ata nggoro descendants can hold the position of adat chief (Mosalaki), while the descendants of ata mai occupy the second layer in their society as anakalo fa'é walu (commoners). ${ }^{39}$

The chief of adat maintains extensive power over a specific area where he carries out his duties that derive from his position. His authority ranges from political to economic matters and adat rituals. As the customary holder of authority over the land, the chief of adat controls the use of land within his realm. The chief of adat is authorized to distribute land to ana darinia (patrilineal descendants of Mosalaki's

${ }^{36}$ Ibid., p. 122.

37 J. Emmed M. Prioharyono, "The Mosalaki's Political Power and Adat in Nggela and Tenda Villages, Ende Regency, Flores" ["Kekuasaan Politik dan Adat Para Mosalaki di Desa Nggela dan Tenda, Kabupaten Ende, Flores], Antropologi Indonesia (Indonesian Journal on Social and Cultural Anthropology) Vol. 33 No. 3 (September - December 2012).

${ }^{38}$ Ibid.

${ }^{39}$ Ibid.,: 192. 
clan) and grant the rights to use cultivated land (watas) to the commoners (anakalo fa'é walu). ${ }^{40}$

Adat tenure does not recognize individual ownership because ulayat land is perceived as a communal property and thus cannot be sold individually or be registered on an individual basis. Control over land is created, maintained, and protected by adat system according to the local wisdom and knowledge. Land exchange through sale and purchase or rent is usually limited among the community members. Outside parties can obtain access to the land with the approval of the chief of adat, after they provide a customary payment (usually money and cattle such as buffaloes, cows, and so on) through adat ceremonies. Furthermore, alienation or pawning of communal land can be done only with the chief's consent, on behalf of the tribal/kinship group. However, the land is still considered to belong to adat and should be returned to the community after the tenure is completed. ${ }^{41}$

Problems arise when the practice of transferring rights to external parties becomes very extensive and when the adat mechanism is insufficient to accommodate them. ${ }^{42}$ In line with the changes over time, including cultural changes, land has become a commodity, leading to conflicts of interests over land possession and provoking land disputes. Prior notes that, "as monetary needs increase by the year, the unity of the village is strained by the competing needs of individual families who feel that they need to sell land, this intensifies struggle within and between villages over land claims." The involvement of outsiders in land acquisition for business interests aggravates the conflicts over land ownership in Flores.

Table 1: Conflict Incidences in Flores, $2001-2003^{43}$

\begin{tabular}{lrrrr}
\hline \multicolumn{1}{c}{ District } & $\begin{array}{c}\text { General } \\
\text { Conflicts }\end{array}$ & \multicolumn{2}{c}{ Land and Natural Resources Conflicts } \\
Total & & $\begin{array}{c}\text { Resulted in } \\
\text { Violence }\end{array}$ & $\begin{array}{c}\text { Resulted in } \\
\text { Death }\end{array}$ \\
\hline Ende & 83 & 16 & 7 & 3 \\
East Flores & 104 & 25 & 9 & 5 \\
Manggarai & 108 & 44 & 24 & 15 \\
Ngada & 76 & 24 & 10 & 1 \\
Sikka & 82 & 14 & 6 & 2 \\
\multicolumn{1}{c}{ Total } & $\mathbf{4 5 3}$ & $\mathbf{1 2 3}$ & $\mathbf{5 6}$ & $\mathbf{2 6}$ \\
\hline \multicolumn{1}{c}{} & & & &
\end{tabular}

\footnotetext{
${ }^{40}$ Ibid.,: 182.

${ }^{41}$ Afrizal, "Oil Palm Plantations, Customary Rights, and Local Protest: A West Sumatran Case Study," in Land for the People: The State and Agrarian Conflict in Indonesia, edited by Anton Lucas and Carol Warren, (Athens: Ohio University Press, 2013), pp. 151-152.

${ }^{42}$ World Bank, World Development Report 2006: Equality and Development (New York: Oxford University Press, 2005), p. 166.

${ }^{43}$ Samuel Clark,ed., More Than Just Ownership: Ten Land and Natural Resource Conflict Case Studies from East Java and Flores, (Conflict and Community Development Research and Analytical Program, Indonesian Social Development Paper No. 4), (The World Bank, 2004), p. 7.
} 


\section{B. The Role of Adat Chief in Dispute Resolution}

The chief of adat (Mosalaki) plays a central role in the process of dispute resolution as the justice of the peace. He acts as the mediator in resolving any kind of disputes between inhabitants of the same village, including disputes over land. He is seen as the pillar who upholds adat law, and thus he becomes the primary actor in the society for settling problems. Since there are no strict rules for resolving conflicts, the chief of adat decides which approach and adat rule to apply in each case. The primary means of dispute resolution is mediation in which the chief of adat will seek reconciliation to achieve the best interests of the disputing parties. This process is crucial in maintaining peacefulness and establishing order within this society.

Generally, the dispute resolution process based on adat law can proceed as follows. A land dispute typically starts with a complaint or report to the chief of adat by the party involved in the dispute or the victims. The chief of adat then follows up the complaint by sending a notice for disputing parties to be present in an adat hearing at an appointed time and place. The adjudication process begins with adat rituals and prayer, led by the chief of adat. As a mediator, the chief of adat asks the disputing parties to explain their standing in the dispute and show the supporting proof for their claim. The process involves testimony of witnesses relevant to the case to strengthen the claim of each party. ${ }^{44}$

After both parties have the opportunity to explain their case, the chief of adat as the mediator delivers his view based on the facts presented in the adjudication process. He then offers his resolution to the dispute. These adat hearings can take place several times until the parties settle the dispute. If they finally reach an agreement, the chief of adat produces a written testament signed by the parties, indicating that the dispute is over. ${ }^{45}$

The main purpose of adat dispute settlement is reconciliation based on a win-win solution for the disputing parties. The moral authority of the chief of adat contributes to dispute mediation by calming anger and hostility among the disputing parties. The key outcome of adat resolution is that once a matter has been settled the parties will not bring it up again. An individual who violates adat's decision will suffer punitive action in the form of adat fines and other social sanctions. ${ }^{46}$

However, if adat mechanism fails to end the conflict, the chief of adat facilitates further negotiation between both parties until they reach agreement or find another way to settle their dispute. Not infrequently, the chief of adat suggests that the disputing parties appeal to higher administrative officials such as the head of the subdistrict or regent. They may also bring the case before the state court, as a last resort.

In this regard, the case of Ngada residents can be seen as a perfect example of adat institutions' failure to accommodate the interests of parties from different villages, because the parties eventually decide to settle their conflict through the involvement of state apparatus.

\footnotetext{
${ }^{44}$ Muga, loc.cit.

${ }^{45}$ Ibid.

${ }^{46}$ Prioharyono, op.cit.,: 195.
} 


\section{Land Conflict Case in Ngada}

Ngada is one of the eight regencies in Flores, described as having a tropical dry climate and consisting mostly of savanna and meadow. Ngada's climate determines the population's livelihoods, primarily farming, forestry, hunting, and fishery. ${ }^{47}$ In 2008 , farming contributed $45.71 \%$ of gross product domestic regional of Ngada regency. ${ }^{48}$ Under current arrangements the Ngada regency covers an area of 1,620.92 km and is divided into nine districts, 78 villages, and 16 urban villages, with a population of $138,050 .^{49}$

In this case, the disputing parties are people from the villages of Seso (Meli tribe) and Waepana, both located within the district of Soa. The object of the dispute is an area of 10 hectares of ulayat land located in Turewuda, Waepana village. The Meli tribe of Seso village claim that the land belonged to their ancestors as the site of their customary ritual practices and as fields for shepherding and hunting. The source of the dispute is related to what Davidson and Henley call "the continuity between contemporary claims and the past practices." ${ }^{\prime 0}$ Its origin dates back to the Dutch colonization era when the Seso village was under the Bajawa kingdom. The king of Bajawa (at the time, the chief of the Meli tribe) made an arrangement with the Dutch government to divide land in the district of Soa into two parts. ${ }^{51}$

The eastern part of the land was given to the Dutch and was often called "Vanback" land, while the western part was still under the control of the people of Seso village. After the Independence, the Indonesian government appropriated the Vanback land and declared it as state land. The conversion of Vanback land to state land was followed by a redistribution program in which the government allotted the land to the people without considering tribal origins and other historical factors. This program attracted settlers outside the Meli tribe to inhabit and take control of the land for years. The area where the former Vanback land was located came to be called Turewuda area in Waepana village and was the object of the dispute. ${ }^{52}$

An increasing population and monetized local economy, combined with traditional claims over land, are among the driving factors of land conflicts in Ngada. In particular, people from Seso village depict people from Waepana as robbers of their customary land. On the other hand, people from Waepana who have been living there for decades perceive themselves to be the parties most entitled to the disputed land. They even own official land certificates issued by the government. ${ }^{53}$

At first, the disputing parties employed adat institutions through a mechanism that was mediated by the chief of adat. As bilateral negotiations between the two villages failed, the parties sought the intervention of a third party as mediator to facilitate communication between the disputants. They believed it was better to employ state officials who were considered to be the neutral party to resolve the dispute. The people from Seso village then made a complaint report to the National Land Agency (Badan Pertanahan Nasional/BPN) of the Ngada regency.

Unfortunately, the author could not get access to more detailed information about

\footnotetext{
${ }^{47}$ National Labor Force Survey, 2008, BPS - Statistics Indonesia, in Ngada in Figures 2009. p. 85

${ }^{48}$ Ibid., p. 353

${ }^{49}$ Ibid. p. 6.

${ }^{50}$ Davidson and Henley,op.cit., p. 2.

${ }^{51}$ Muga, op.cit., pp. 62-64.

${ }^{52}$ Ibid.

${ }^{53}$ Ibid.
} 
the mediation process and how the dispute was resolved at this level. However, according to secondary sources, the dispute was solved through a mediation in which the head of local BPN acted as mediator. As a result, the people of Waepana agreed to return the disputed land and pay compensation to the people of Seso. ${ }^{54}$

\section{Where to Place Adat in the Discourse on Informal Institutions?}

The previous section examines adat institution on the assumption that it is a coherent and static body of rules applicable in a given community rather than a diverse and dynamic one. In fact, there is no single or uniform type of adat in Indonesia, and this fact is a clear reflection of ethnic diversity that characterizes the country. Thus, it is misleading to consider adat law as a single and fixed system as opposed to the state legal system.

Contrary to common perception, adat is not a static institution. Adat is a dynamic one because it constantly adapts to changes and evolves over time. Flexibility is inherent in adat as it develops in parallel with the development of the society in which it operates. ${ }^{55}$ In Flores, for example, although traditionally only ata nggoro descendants can hold the chief of adat position, this rule is not strictly applied in all Flores regions. In more heterogeneous areas with many settlers, a commoner can be appointed as the holder of adat authority as long as he meets certain social expectations. For instance, the Lio tribe in Nggela and Tenda villages choose their chief of adat based on his merits and knowledge of Lio's adat and traditions instead of a patrilineal lineage. ${ }^{56}$

This illustration of land dispute resolution in Indonesia, where legal pluralism prevails, offers an interesting account of the tension between adat and national law. Multiple legal orders provide particular sets of rules, attitudes, and beliefs. At the micro level, each ethnic or sub-ethnic group has its own rules and solutions to conflicts over land, as do state institutions. As a result, individuals may choose one legal framework over another to pursue their solutions. ${ }^{57}$ In this regard, social, economic, and political powers play an important role in determining preference for a particular mechanism for resolving land disputes. ${ }^{58}$ As Favali and Pateman contend, "conflicts over land are also conflicts over power, hegemony, and legitimacy." ${ }^{\prime 9}$

However, it is difficult to draw a sharp distinction between formal and informal institution based on a "zero-sum relationship" 60 in which the existence of one

\footnotetext{
${ }^{54}$ Agustinus Esra Bhodo, "Land Dispute Resolution through Mediation in the Ngada Regency by Land Agency for Furthering Legal Utilities” ["Penyelesaian Sengketa Tanah Woe Melalui Mediasi di Kabupaten Ngada oleh Kantor Pertanahan untuk Mewujudkan Kemanfaatan Hukum”], (Master Thesis, Master of Laws Program, University of Atma Jaya Yogyakarta 2013).

${ }^{55}$ Dinnen, op.cit., p. 4.

${ }^{56}$ Prioharyono, op.cit., pp. 190-191.

${ }^{57}$ Literature on legal pluralism shows how people choose one of the multiple sources of justice where competing laws and norms operate at various levels. This phenomenon is often called "forum shopping." See: Ruth S. Meinzen-Dick and Rajendra Pradhan, "Legal Pluralism and Dynamic Property Rights," (Capri Working Paper No. 22, CGIAR Systemwide Program on Collective Action and Property Rights, January 2002), http://www.capri.cgiar.org/pdf/capriwp22.pdf, accessed on 10 March 2014.

58 Brian Z. Tamanaha, "The Rule of Law and Legal Pluralism in Development," (Pluralism in Development, Legal Studies Research Paper Series, Paper No. 11-07-01, July 2011), http://ssrn.com/abstract $=1886572$, accessed on 5 March 2014, p. 22.

${ }^{59}$ Favali and Pateman, op.cit., p. 132.

60 Lauren M. Maclean, Informal Institutions and Citizenship in Rural Africa: Risk and Reciprocity in
} 
institution would imply the absence of the other. Many scholars tend to employ "dichotomous formulation" such as state and non-state actors, formal and informal institutions, and traditional and modern justice as if these institutions operate within "discrete and separate spheres of justice." ${ }^{61}$ In practice, they do not operate separately or in isolation from each other. ${ }^{62}$ Rather, there is co-existence, institutional overlaps, and interactions among these various legal orders.

Some informal dispute mechanisms involve actors from both the state apparatus such as the police or local government officials and informal sector such as chiefs of adat, religious leaders, or community elders. The same actor can function as a double agent, representing adat and formal institutions. This would be the case, for example, where the chief of adat is concurrently the head of the local government or a police officer. $^{63}$ In addition, the procedures applied in an informal dispute resolution could refer to adat law or the combination of formal and informal rules. ${ }^{64}$

\section{Broader Implication for Theoretical Debates on Property Rights Institutions}

People devise institutions to reduce uncertainty, overcome "social dilemmas,"65 and thus minimize transaction costs. ${ }^{66}$ In short, institutions structure people's "deliberations and decisions," "organize all forms of repetitive and structured interactions" and thus shape people's behaviours. ${ }^{67}$

Parlevliet provides a helpful clarification of the concept of institution by laying out three definitions. ${ }^{68}$ The first defines institutions as "rules of games." North introduces this narrow understanding of institutions by defining them as "humanly devised constraints that structure political, economic and social interaction." ${ }^{69}$ These constraints can be in the form of either formal or informal rules. The second defines institutions as "rules and behavioural practices." This definition is important to explain why illicit behaviour such as corruption and clientelism fall into the category of informal institutions. The last definition posits that institutions are "rules and organization." It points to an overlapping, sometimes confusing, account of the difference between institutions and organizations. In common usage, institutions and organizations are often used interchangeably; thus it remains debatable whether or not it is useful to make a distinction between the two. ${ }^{70}$

While most scholars have reached a broad consensus that institutions are related

Ghana and Côte d'Ivoire (Cambridge: Cambridge University Press, 2010), p. 11.

${ }^{61}$ Dinnen, op.cit., p. 7.

${ }^{62}$ Ibid.

${ }^{63}$ Ibid.

${ }^{64}$ World Bank, op.cit., p. 3.

65 Elinor Ostrom, Understanding Institutional Diversity (Princeton, NJ: Princeton University Press, 2005), p. 125.

${ }^{66}$ Douglass C. North (2), Institutions, Institutional Change, and Economic Performance. (Cambridge: Cambridge University Press, 1990).

${ }^{67}$ Ostrom, op.cit., p. 3.

${ }^{68}$ Jante Parlevliet, "In Focus: Defining (Informal) Institutions," in Informal Institutions: How Social Norms Help or Hinder Development, edited by Johannes Jütting, Denis Drechsler, Sebastian Bartsch and Indra de Soysa, (OECD, 2007), http://browse.oecdbookshop.org/oecd/pdfs/product/4107101e.pdf, accessed on 5 March 2014.

${ }^{69}$ North (2), op.cit,, p. 3.

${ }^{70}$ Parlevliet, op.cit., pp. 44-45. 
to economic growth and development, they diverge in the way they categorize institutions and the way institutions can contribute to the society. Previous studies predominantly treat formal institutions as determinant factors in realizing desirable developmental outcomes. ${ }^{71}$ Later scholars, however, cast doubt on the notion of formal institutions as the only source of economic growth. They contend that informal institutions should also be taken into account. ${ }^{72}$

Debate about property rights institutions also revolves around an even further distinction between institutions: whether formal or informal institutions and whether private or communal systems are effective in revealing productive potential of property rights. A dominant view in this debate is that formalized private property rights are pivotal in providing land tenure security and thus encouraging development and economic growth. ${ }^{73}$ Seller, on the other hand, contends that it is customary land tenure that generates productive investment and thus promotes sustained economic growth in Akyem Abuakwa, a traditional entity in Ghana. She then suggests that enforcement is the key element in securing property rights regardless of whether or not the system is operating under private property rights or customary land tenure. ${ }^{74}$

Brule' provides an examination on the relationship between formal and informal institutions related to land rights in rural North India. Central to her analysis is the question about the role of formal and informal property rights institutions in resolving land dispute. She contends that Indian caste system plays a significant role in determining formal adjudication outcomes. Some influential castes enjoy greater access to economic resources and legal security than the less influential ones. As a result, India's formal court does not provide equal treatment to all castes, favouring some castes at the expense of the others. ${ }^{75}$ Her finding suggests that informal institutions are complementary to the formal ones. Informal institutions such as caste system operate as a means of coordinating interests within the same caste, while the formal ones provide law enforcement through its coercive power. A combined use of both formal and informal institutions will result in a more efficient land dispute resolution. ${ }^{76}$

This paper contributes to the debate on how formal and informal institutions are used to secure property rights and to resolve dispute over land. Adat plays major role in resolving land disputes in Flores, East Nusa Tenggara. It provides certain levels of security and has proven to be effective in resolving conflicts in a relatively closed and homogenous community setting. It offers a greater accessibility, flexibility, and legitimacy that support reconciliation process between the disputing parties. If the disputes remain unresolved, a neutral mediator or umpire is called in with the authority to impose a decision.

However, despite its advantages in dispute resolution, adat possesses certain

71 Among others: North 1981, 1990; North and Weingast 1989; Acemoglu, Johnson and Robinson 2001; and Easterly and Levine 2004.

72 Among others: Sellers 1995; James Scott 1998; Rodrik, Subramanian and Trebbi 2002; Haber et al. 2003; Jütting et al. 2007; Brule's 2009.

${ }^{73}$ Among others: Harrison 1987; World Bank 1974, 2003; de Soto 2000.

${ }^{74}$ Sellers, op.cit., p. 878.

${ }^{75}$ Rachel Brule', "Land Rights without Laws: Understanding Property Rights Institutions, Growth, and Development in Rural India," (CDDRL Working Papers, Number 98 February 2009, Center on Democracy, Development, and the Rule of Law Freeman Spogli Institute for International Studies, Stanford University), http://cddrl.stanford.edu, accessed on 5 March 2014.

${ }^{76}$ Ibid., p. 3. 
limitations, particularly when the dispute involves exogenous parties such as other ethnic groups or settlers. Given its narrow scope of jurisdiction, "adat cannot normally function as a sovereign authority for adjudicating disputes among parties of different origin."77 It has also proven to be powerless against the state (central or local government) and private corporations.

Furthermore, this paper finds that there is interplay between adat and state institutions, in which the action of one institution inevitably affects the other. The interaction between adat and state law brings about the issue on the relationship between formal and informal institutions. According to Helmke and Levitsky, informal institutions interact with formal ones in four ways: complementary, accommodating, competing and substitutive. ${ }^{78}$

The relationship between adat and state institutions varies, depending on the context. Adat rules may or may not conflict with the state rules, but unless we look at a particular dispute, we cannot see in practice how they interrelate. ${ }^{79}$ In some circumstances, adat may serve as an alternative institution to the state legal system. For example, a state official may choose direct cases to adat mechanism. Likewise, the chief of adat may refer certain cases such as serious crimes (murder, terrorism, and so forth) to the police. In other cases, adat institutions may operate in a complementary manner with the formal ones, in which adat provides social mechanisms in ensuring the obedience to a particular state law. Furthermore, adat may also compete with the state law when it imposes discriminatory provisions toward women, maintains social inequality, and violates the principles of due process of law.

Using as an example the case of land disputes in Ngada regency, this paper discusses the causes and the traditional rules that have been devised to settle them. What is particularly interesting in the case of Ngada is that state apparatus applied adat law in mediating the dispute, rather than tried to impose the state law. According to the state law, a land certificate is the highest proof of land ownership. Had the state law been used to resolve the dispute, it should have ruled/arbitrated in favour of the people from Waepana who owned land certificates. However, it turned out that the mediation was won by the people of Seso who claimed their rights on the basis of adat law.

It confirms Reerink's study that "semi-formal tenure" based on adat rights may provide strong security, in a sense that it offers "actual protection" to the landholders "against involuntary removal, irrespective of the legal status of land tenure." ${ }^{80}$ This thesis has broad implications for theoretical debates concerning matters such as (1) the way property rights over land should be enforced; (2) the relationship between formalized land title and tenure security; and (3) the conditions in which semi-formal tenures provide strong a sense of security. Further investigation on these issues is necessary to examine the relationship between land tittles and tenure security.

\footnotetext{
${ }^{77}$ Ibid., p. 37.

${ }^{78}$ Gretchen Helmke and Steven Levitsky, eds., Informal Institutions and Democracy: Lessons from Latin America (Maryland: John Hopkins University Press, 2006).

${ }^{79}$ Favali and Pateman, op.cit., p. 132.

${ }^{80}$ Gustaaf Reerink, Tenure Security for Indonesia's Urban Poor: A Socio-Legal Study on Land, Decentralisation, and the Rule of Law in Bandung (Leiden: Leiden University Press, 2011).
} 


\section{Conclusion}

By employing the case of land dispute resolution in Flores, this paper offers an account on how people in Flores resolve their disputes in cooperative and amicable fashion, without the involvement of state institutions. This finding seems to support Ellickson's suggestion that better-enforced and less costly local systems of rules and sanctions often exist without the involvement of state. ${ }^{81}$ Ellickson utilizes a case of cattle-trespass damage in Shasta County to illustrate how ranchers and farmers settle their disputes. Unlike Coase's suggestion, ${ }^{82}$ residents in Shasta County do not employ legal entitlement as a starting point for bargaining due to their limited knowledge about law. Instead, they use "commonsense" to reach "mutual advantage."

This paper, however, challenges Ellickson's argument for his narrow understanding of law as statutory, written rule that is passed by legislative bodies. Adat communities apply customary law which consists of sets of rules, beliefs, and principles embodied in their society. Hierarchical coordination flow is present in adat law, albeit not formally institutionalized. Therefore, rather than confirming that social order can be achieved without law, this paper suggests that it can be attained without the state intervention.

\section{Bibliography}

\section{Books}

Asia Foundation. Citizens' Perceptions of the Indonesian Justice Sector. Jakarta: Asia Foundation, 2001.

Bowen, John R. Islam, Law, and Equality in Indonesia. Cambridge: Cambridge University Press, 2003.

Davidson, Jamie S. and David Henley. Eds. The Revival of Tradition in Indonesian Politics: The Deployment of Adat from Colonialism to Indigenism. New York: Routledge, 2007.

Ellickson, Robert. Order Without Law: How Neighbors Settle Disputes. Massachusetts: Harvard University Press, 1991.

Favali, Lyda and Roy Pateman. Blood, Land, and Sex: Legal and Political Pluralism in Eritrea. Bloomington: Indiana University Press, 2003.

Haber, Stephen, Armando Razo, and Noel Maurer. The Politics of Property Rights: Political Instability, Credible Commitments and Economic Growth in Mexico. Cambridge: Cambridge University Press, 2003.

Helmke, Gretchen and Steven Levitsky. Eds. Informal Institutions and Democracy: Lessons from Latin America. Maryland: John Hopkins University Press, 2006.

Hooker, M. B. Adat Law in Modern Indonesia. New York: Oxford University Press, 1978. Jütting, Johannes, Denis Drechsler, Sebastian Bartsch, and Indra de Soysa. Eds. "Informal Institutions: How Social Norms Help or Hinder Development." (OECD, 2007). http://browse.oecdbookshop.org/oecd/pdfs/product/4107101e.pdf. Accessed on 5 March 2014.

Lindsey, Tim. Indonesia, Law and Society. $2^{\text {nd }}$ ed. New South Wales: The Federation Press, 2008.

\footnotetext{
${ }^{81}$ Robert Ellickson, Order Without Law: How Neighbors Settle Disputes (Massachusetts: Harvard University Press, 1991).

82 Ronald H. Coase, “The Problem of Social Cost," The Journal of Law \& Economics Vol. 3 (1960).
} 
Lucas, Anton and Carol Warren. Eds. Land for the People: The State and Agrarian Conflict in Indonesia. Athens: Ohio University Press, 2013.

Maclean, Lauren M. Informal Institutions and Citizenship in Rural Africa: Risk and Reciprocity in Ghana and Côte d'Ivoire. Cambridge: Cambridge University Press, 2010.

North, Douglass C. Institutions, Institutional Change, and Economic Performance. Cambridge: Cambridge University Press, 1990.

Ostrom, Elinor. Understanding Institutional Diversity. Princeton, NJ: Princeton University Press, 2005.

Pompe, Sebastiaan. The Indonesian Supreme Court: A Study of Institutional Collapse. Ithaca: Cornell Southeast Asia Program Publication, 2005.

Reerink, Gustaaf. Tenure Security for Indonesia's Urban Poor: A Socio-Legal Study on Land, Decentralisation, and the Rule of Law in Bandung. Leiden: Leiden University Press, 2011.

World Bank. Justice for the Poor: Forging the Middle Ground: Engaging Non-State Justice in Indonesia [Menemukan Titik Keseimbangan: Mempertimbangkan Keadilan Non-Negara di Indonesia]. Jakarta: World Bank, 2009.

World Bank. World Development Report 2006: Equality and Development. New York: Oxford University Press, 2005.

\section{Articles}

Afrizal. "Oil Palm Plantations, Customary Rights, and Local Protest: A West Sumatran Case Study." In Land for the People: The State and Agrarian Conflict in Indonesia. Edited by Anton Lucas and Carol Warren. Athens: Ohio University Press, 2013.

Bedner, Adriaan and Stijn van Huis. "The Return of the Native in Indonesian Law: Indigenous Communities in Indonesian Legislation." Bijdragen tot de Taal-, Land-en Volkenkunde Vol. 164 No. 2/3 (2008): 165-193.

Bhodo, Agustinus Esra. "Land Dispute Resolution through Mediation in the Ngada Regency by Land Agency for Furthering Legal Utilities" ["Penyelesaian Sengketa Tanah Woe Melalui Mediasi di Kabupaten Ngada oleh Kantor Pertanahan untuk Mewujudkan Kemanfaatan Hukum"]. Master Thesis, Master of Laws Program, University of Atma Jaya Yogyakarta, 2013.

Brule', Rachel. "Land Rights without Laws: Understanding Property Rights Institutions, Growth, and Development in Rural India." CDDRL Working Papers, Number 98 February 2009, Center on Democracy, Development, and the Rule of Law. Freeman Spogli Institute for International Studies, Stanford University. http:// cddrl.stanford.edu. Accessed on 5 March 2014.

Clark, Samuel (ed.). More than Just Ownership: Ten Land and Natural Resource Conflict Case Studies from East Java and Flores. Conflict and Community Development Research and Analytical Program, Indonesian Social Development Paper No. 4. The World Bank, 2004.

Coase, Ronald H. "The Problem of Social Cost," The Journal of Law \& Economics 3 (1960).

Dinnen, Sinclair. “'Traditional' Justice Systems in the Pacific, Indonesia and TimorLeste." Presented at the 2009 Justice for Children in the Pacific, Indonesia and Timor-Leste, EAPRO Sub-Regional Workshop, April 2009. www.unicef.org/ tdad/uniceftradpacificindonesiatimor09.doc. Accessed on 1 March 2014.

Golub, Stephe. "Beyond Rule of Law Orthodoxy: the Legal Empowerment Alternative," Working Paper No. 14. Washington DC, 2003. 
McMillan, John and Christopher Woodruff. "Private Order under Dysfunctional Public Order." Michigan Law Review 98 (1999): 2421-2458.

Meinzen-Dick, Ruth S. and Rajendra Pradhan. "Legal Pluralism and Dynamic Property Rights." Capri Working Paper No. 22, CGIAR Systemwide Program on Collective Action and Property Rights, January 2002. http://www.capri.cgiar.org/pdf/ capriwp22.pdf. Accessed on 10 March 2014.

Muga, Maria D. "The Role of the Chief of Adat in Land Conflict Resolution through Mediation: Case Study Ulayat Land Case at the District of SOA, Ngada, Flores, East Nusa Tenggara" ["Peranan Kepala Adat dalam Penyelesaian Sengketa Tanah Ulayat Melalui Mediasi: Studi Analisa Terhadap Penyelesaian Sengketa Tanah, Tanah Ulayat di Kecamatan SOA Kabupaten Ngada, Flores, Propinsi Nusa Tenggara Timur"]. Thesis at the Magister Program of Notary, University of Diponegoro, Semarang, 2008.

North, Douglass C. "Institutions and Credible Commitment." http://dlc.dlib.indiana. edu/dlc/bitstream/handle/10535/3711/9412002.pdf?...1. Accessed on 24 February 2014.

Parlevliet, Jante. "In Focus: Defining (Informal) Institutions." In Informal Institutions: How Social Norms Help or Hinder Development. Edited by Johannes Jütting, Denis Drechsler, Sebastian Bartsch, and Indra de Soysa. OECD, 2007. http:// browse.oecdbookshop.org/oecd/pdfs/product/4107101e.pdf. Accessed on 5 March 2014.

Prioharyono, J. Emmed M. “The Mosalaki's Political Power and Adat in Nggela and Tenda Villages, the Ende Regency, Flores" ["Kekuasaan Politik dan Adat Para Mosalaki di Desa Nggela dan Tenda, Kabupaten Ende, Flores"] Antropologi Indonesia (Indonesian Journal on Social and Cultural Anthropology) Vol. 33 No. 3 (September - December 2012).

Sellers, Kathryn Firmin A. "The Politics of Property Rights." American Political Science Review Vol. 89 No. 4 (December 1995): 867-881.

Tamanaha, Brian Z. "The Rule of Law and Legal Pluralism in Development." Pluralism in Development, Legal Studies Research Paper Series, Paper No. 11-07-01, July 2011. http://ssrn.com/abstract=1886572. Accessed on 5 March 2014.

The Statistics of Ngada Regency, Ngada in Figures 2009 (Ngada dalam Angka 2009).

The World Bank Social Development Unit of Indonesia. "Village Justice in Indonesia: Case Studies on Access to Justice, Village democracy, and Governance." A report from Justice for the Poor Team, The World Bank Social Development Unit of Indonesia, February 2004. http://siteresources.worldbank.org/ INTINDONESIA/Resources/Publication/04-Publication/VilllageJustice+.pdf. Accessed on 1 March 2014.

\section{Websites}

The Embassy of the Republic of Indonesia. "A Diverse National" http://www. embassyofindonesia.org/about/people.htm. Accessed on 15 March 2014. 